\title{
PENERAPAN ALTERNATIF AKAD PEMBIAYAAN HAJI DAN UMRAH PASCA PERATURAN MENTERI NO 24 TAHUN 2016 PADA BANK PANIN DUBAI SYARIAH SURABAYA
}

\author{
Fitrotu Aini \\ Abdul Wahab \\ e-mail:Fitraaini93@gmail.com
}

\begin{abstract}
Hajj as a great symbol of worship. Hajj is the fifth pillar of Islam which is mandatory for every Muslim who are able to da it in accordance with the legal requirement of pilgrimage. One of the legal conditions of Hajj is the capability, capable to cover the cost of the hajj and the family left behind. Panin Bank Dubai Sharia Bank was established based on the regulation of Limited Company No. 12 dated January 8, 1972 by Moeslim Dalidd, a notary in Malang. PT. Bank Panin Dubai Syariah Tbk has been legalized by the Financial Services Authority ("OJK"), in accordance with a copy of the policy of the Board of Commissioners of OJK No. Kep-29 / D.03 / 2016 on July 26, 2016.

Therefore, through this research, the writer wants to understand: (1) how is the practice of applying alternative financial agreement of hajj and umrah after the implementation of regulation made by ministry of religious affair No. 24 year 2016 at Panin Bank Dubai Syariah Surabaya branch? (2) What is the analysis of Islamic law on the practice of multilateral contract alternative application in this Bank? Therefore, this study is aimed to, firstly, understand and describe the application of alternative contracts to hajj and umrah after the regulation of Ministry of Religious Affairs No. 24 of 2016 in Panin Bank Dubai Sharia branch Surabaya, and to describe the analysis of Sharia Economic Law about the practice of applying alternative contract in the bank.

The method used in this research is qualitative method. The research data are taken in natural situation in Panin Bank Dubai Syariah Surabaya. The data are taken during operational hours using case study approach. Are done through interview technique with the main participant, Assistant Manager 1, and document, archive, book, sample of registration, as secondary data source. The data are analyzed through 3 (three) data deduction, display data and ended with conclusion and verification.

The results of the study indicate that the Panin Bank Dubai Sharia runs in accordance with the government regulation No. 24 year 2016 "BPS BPIH is prohibited from providing direct and indirect Hajj money service" including Hajj and Umrah services using various financing products and funds saving, funds collecting in the form of deposits, savings or other forms, using multi-service financing akad wadi'ah, with the savings of hajj services with initial minimum deposit of Rp500,000, and according to customers' ability.
\end{abstract}

Keywords: hajj, umrah, wadi'ah.

\section{PENDAHULUAN}


Haji sebagai syiar yang agung dan ibadah yang mulia, dengannya seorang hamba akan mendapatkan rahmat dan berkah yang menjadikan setiap orang muslim sangat rindu untuk segera melaksanakannya. Pasal 1 Ayat 1 UU Nomor 34 Tahun 2014, menjelaskan bahwa Ibadah haji merupakan rukun Islam kelima yang merupakan kewajiban sekali seumur hidup bagi setiap orang Islam yang mampu menunaikannya. Pasal 2 UU Nomor 34 Tahun 2014 menjelaskan bahwa penyelenggaraan ibadah haji dilaksanakan berdasarkan asas keadilan, profesionalitas, dan akuntabilitas dengan prinsip nirlaba yang bertujuan untuk memberikan pembinaan, pelayanan, dan perlindungan yang sebaik-baiknya bagi Jamaah Haji, sehingga Jamaah Haji dapat menunaikan ibadahnya sesuai dengan ketentuan ajaran agama Islam. ${ }^{1}$

Bank syariah merupakan sebuah hasil pencangkokan budaya barat dan budaya Islam. Lembaga bank muncul dalam tradisi sosio ekonomi budaya barat. Dalam perkembangannya, lembaga ini kemudian tumbuh dan berkembang tidak hanya dalam tradisi sosio ekonomi budaya barat saja, tetapi menjalar ke seluruh pelosok dunia, termasuk menjalar ke dalam masyarakat muslim, bahkan dalam taraf tertentu kelembagaan bank sudah menguasai cara berfikir ekomomi masyarakat Muslim di seluruh penjuru dunia, termasuk di Indonesia. $^{2}$

Keberadaan dua sistem perbankan yang berkembang secara

\footnotetext{
${ }^{1}$ UU No 34 TAHUN 2014 tentang Ibadah Haji,

${ }^{2}$ Norman Anderson, Law reform in the Moslem World (London: The Athlone Press, 1976), 84-85
}

paralel memiliki hubungan keuangan yang terbatas satu sama lain akan menciptakan diversifikasi risiko keuangan secara beragam, yang akhirnya dapat mengurangi problem risiko sistemik pada saat terjadi krisis keuangan. Artinya, pengembangan bank syariah dapat meningkatkan ketahanan sistem perbankan nasional. $^{3}$

Sementara itu, jika wilayah ekonomi dan bisnis dikaitkan dengan ibadah haji, hal ini akan lebih kompleks lagi. Salah satu hal yang sangat terasa di masyarakat berkaitan dengan ibadah haji adalah kemampuan finansial masyarakat dalam usaha memenuhi kewajiban ibadah haji tersebut.Tingginya antusias masyarakat Islam di Indonesia untuk menunaikan ibadah haji, membuat daftar antrean keberangkatan ibadah haji semakin panjang. Bahkan ada daerah yang daftar tunggu hajinya bisa lebih dari 15 tahun,karena kuota yang dibatasi oleh pemerintah.Dikarenakan jumlah jamaah haji yang semakin meningkat dari tahun ketahun.Penyelenggaran haji selalu menjadi topik pembicaraan hangat dikalangan masyarakat. Hal ini karena tuntutan publik di era reformasi dan keterbukaan dan kenyataan bahwa haji bukan hanya rutinitas tahunan yang menjadi kewajiban umat islam dalam menyempurnakan rukun Islam yang kelima.

Dalam menjalankan setiap kegiatannya LKS atau Bank Syariah harus mengikuti prinsipprinsip syariah.Dalam prinsip Hukum Muamalat disebutkan bahwa segala bentuk muamalat dibolehkan kecuali

\footnotetext{
${ }^{3}$ Ryan Kiryanto, Konversi Bank Konvensional Ke Bank Syariah, (Suara Karya, 2001), 2-6
} 
yang dilarang oleh syari.Seperti halnya dengan penggunaan akad.Setiap produk yang dikeluarkan oleh LKS harus menggunakan akad yang tepat.

Bank Panin Syariah merupakan bank syariah pertama yang melakukan initial public offering dan telah listing pada tahun 2014. Perusahaan yang telah melaukan go public atau initial public offering akan memiliki dana yang besar dari hasil penjualan saham yang dilakukan di pasar modal. Kegiatan go public secara teori dapat berpengaruh terhadap kondisi perusahaan dan kinerja keuangan bank. Dengan adanya perubahan perusahaan menjadi perusahaan publik maka diharapkan kinerja perusahaan tersebut akan mengalami peningkatan dan perusahaan akan menerima keuntungan yang bertambah. Semakin banyaknya perusahaan perbankan yang melakukan go public maka persaingan pada sektor pasar modal semakin ketat pula, perusahaan harus lebih memaksimalkan kinerja keuanganya agar mampu memikat para investor.

Dalam perkembangannya,

Bank syariah harus mengikuti kebutuhan nasabah yang semakin hari semakin bervariasi, yang mnyebabkan munculnya jenis-jenis produk pembiayaan baru.

Ketentuan tentang

pembiayaan pengurusan haji dan umrah perbankkan syariah diatur dalam Peraturan Menteri Agama Republik Indonesia Nomor 24 tahun 2016 "Bank Penerima Setoran Biaya Penyelenggaraan Ibadah Haji" Menyatakan peraturan menteri agama tentang bank penerima setoran biaya penyelenggaraan ibadah haji. Biaya penyelenggaraan
Ibadah Haji BPIH, dalam pengelolaannya mempunyai kegiatan perencanaan, penerimaan, pengeluaran, pengembangan, akuntansi, pelaporan dan pertanggungjawaban BPIH.yang mempunyai syarat berbadan hukum perseroan terbatas, memiliki sarana prasarana, dan kapasitas untuk berintegrasi dengan sistem layanan haji kementrian Agama, memiliki kondisi kesehatan bank sesuai dengan peraturan Bank Indonesia atau Otoritas jasa Keuangan (OJK). Namun dalam pasal 6 A Peraturan Menteri Agama Republik Indonesia Nomor 24 tahun 2016 berbunyi "BPS BPIH dilarang memberikan layanandana talangan haji baik secara langsung maupun tidak langsung". 4

Keberadaan Bank Panin Dubai Syariah sebagai perbankan syariah di Indonesia, yang menggunakan berbagai produk pembiayaan dan menyimpan dana, kegiatan bank panin dubai syariah, sesuai anggaran dasar, sebagai Menyediakan pembiayaan, Melakukan kegiatan penyertaan modal sementara, Menghimpun dana dalam bentuk simpanan berupa giro, tabungan atau bentuk lainnya, Menghimpun dana dalam bentuk investasi berupa deposito, tabungan satau bentuk lainnya,

\section{PEMBAHASAN}

Salah satu usaha untuk merealisasikan prinsip-prinsip ekonomi Islam dalam aktivitas masyarakat secara nyata adalah dengan mendirikan lembaga-

\footnotetext{
${ }^{4}$ Peraturan Menteri No 24 tahun 2016 tentang perubahan atas peraturan Menteri Agama No 30 tahun 2013 tentang Bank Penerima Setoran biaya Penyelenggaraan Ibadah Haji.
} 
lembagakeuangan yang beroperasi berdasarkan syariat Islam. Dari berbagai jenis lembaga keuangan, perbankan merupakan sektor yang paling memberikan pengaruh yang besar dalam aktivitas perekonomian masyarakat modern.

Said Sa'ad Marthan, pemerhati ekonomi Islam Timur Tengah mengungkapkan bahwa bank syariah ialah lembaga investasi yang beroperasi sesuai dengan asas syariah. Sumber dana yang dikelola harus sesuai dengan syar'i dan tujuan alokasi investasi yang dilakukan yaitu membangun ekonomi dan sosial masyarakat serta melakukan pelayanan perbankan yang sesuai dengan nilai-nilai syariah. Bank syariah tidakhanya mencari keuntungan dalam pengoperasian semata, tetapi terdapat nilai-nilai sosial kemasyarakatan dan spiritual yang ingin dicapai. ${ }^{5}$

Seiring

dengan

perkembangan gagasan mengenai perbankan syariah, lahirlah bank syariah sebagai aktualisasi dari teori yang disampaikan oleh cendikiawan atau pera ahli perbankan syariah. Kelahiran perbankan syariah dilandasi dengan dua gerakan renaissance Islam modern yakni neorevivalis dan modernis. Tujuan yang ditemukan dari pendirian lembaga keuangan berdasarkan etika Islam adalah sebagai upaya kaum muslim untuk mendasari segenap aspek kehidupan ekonominya berlandaskan al-qur'an dan hadits. ${ }^{6}$

Dalam sejarah perekonomian kaum muslimin, pembiayaan yang dilakukan dengan akad yang sesuai

\footnotetext{
${ }^{5}$ A Djazuli, Lembaga-lemaga Perekonomian umat, sebuah pengantar, (Jakarta, Rajawali Grafindo Persada, 2002), 54

${ }^{6}$ Syafi'i Antonio, Bank Syariah: dari Teori

Praktik, (Jakarta: Gema Insani, 2001), 18
}

dengan syariah telah menjadibagian dari tradisi umat Islam sejak zaman Rasulullah saw. Pelaksanaanpelaksanaan seperti menerima titipan harta meminjamkan uang ntuk keperluan konsumtif dan bisnis serta melakukan pengiriman uang, telah lazim dilakukan sejak zaman Rasullah. $^{7}$

Ide pendirian bank syariah di Indonesia muncul pada tahun 1970, penyampaian ide muncul dalam seminar hubungan Indonesia-Timur Tengah pada tahun 1974 dan 1976 dalam seminar yang diselenggarakan oleh Lembaga Studi Ilmu Kemasyarakatan dan Yayasan Bhineka Tunggal Ika. sesuai dengan perkembangannya kaum intelektual dan cendikiawan muslim memiliki kesadaran dalam pemberdayaan ekonomi masyarakat. Bank syariah yang menetapkan prinsip bagi hasil belum diatur dan tidak sejalan dengan UU pokok perbankan yang berlaku UU no 14 tahun $1967 .{ }^{8}$

Panin Dubai Syariah Bank didirikan berdasarkan Akta Perseroan Terbatas No. 12 tanggal 8 Januari 1972, yang dibuat oleh Moeslim Dalidd, Notaris di Malang dengan nama PT Bank Pasar Bersaudara Djaja.Panin Dubai Syariah Bank telah beberapa kali melakukan perubahan nama, berturut-turut menjadi PT Bank Bersaudara Djaja, berdasarkan Akta Berita Acara Rapat No. 25 tanggal 8 Januari 1990, yang dibuat oleh Indrawati Setiabudhi, S.H., Notaris di Malang. Kemudian menjadi PT Bank Harfa berdasarkan Akta Berita Acara No. 27 tanggal 27 Maret 1997

\footnotetext{
${ }^{7}$ Ibid, 52

${ }^{8}$ Adrian Sutedi, Perbankan syariah: Tinjauan dan Beberapa segi hukum, (Jakarta: Ghalia Indonesia, 2009,) 92
} 
yang dibuat oleh Alfian Yahya, S.H., Notaris di Surabaya. Kemudian menjadi PT Bank Panin Syariah sehubungan bank perubahan kegiatan usaha dari semula menjalankan kegiatan usaha perbankan konvensional menjadi kegiatan usaha perbankan syariah dengan prinsip bagi hasil berdasarkan syariat Islam, berdasarkan Akta Berita Acara RUPS Luar Biasa No. 1 tanggal 3 Agustus 2009, yang dibuat oleh Drs. Bambang Tedjo Anggono Budi, S,H., M.Kn., pengganti dari Sutjipto, S.H., Notaris di Jakarta.

Berdasarkan Pasal 3 Anggaran Dasar Panin Dubai Syariah Bank sebagaimana termuat dalam Akta Pernyataan Keputusan RUPS Luar Biasa No. 5 tanggal 2 Oktober 2015 yang dibuat oleh Fathiah Helmi, S.H., Notaris di Jakarta, yang telah diberitahukan kepada Menteri Hukum dan Hak Asasi Manusia RI sesuai Surat Penerimaan Pemberitahuan Perubahan Anggaran Dasar dari Menteri Hukum dan Hak Asasi Manusia RI No. AHUAH.01.03-0973015 tanggal 19 Oktober 2015, kegiatan usaha Panin Dubai Syariah Bank adalah: a) Menyediakan pembiayaan, b) Melakuka kegiatan penyertaan modal sementara, c), menghimpun dana dalam bentuk investasi berupa deposito, tabungan atau bentuk lainnya, dll

Bank Panin Dubai Syariah telah ditunjuk oleh kementrian Agama sebagai Bank penerima biaya penyelenggaraan Ibadah Haji (BPIIH), Tabungan Haji Pas merupakan produk yang akan mengakomodasi keberangkatan haji para calon dan nasabah Bank Panin Dubai Syariah.kantor cabang Bank Panin Dubai Syariah yang menghendel semua pendanaan semua apapun salah satunya di pendanaan haji, pendanaan ada dua macam corpored dan retail, di Bank Panin Dubai Syariah banyak pendanaan tabungan yang di tawarkan ada 8 macam

1) Pas

2) Pas Sembako

3) Fleksitel

4) Bisnis

5) Rencana Biasa

6) Rencana Pendidikan

7) Hajidan Umrah Salah satu yang di tawarkan

Bank Panin Dubai Syariah pendanaan Haji. dalam pendanaan tersebut ada Corpored yang di gunakan untuk nama PT yang deposito minimal 2,5 Milyad, Di bank Panin Dubai Syariah mengunakan retail yakni perorangan, yang deposito di bawah 2 milyar, tabungan Haji di sini pasti retail nasabah bisa manabung minmal tiap bulannya hanya 100.000,-dan masing-masing retail atau corpored itu mempunyai kode, jadi ada dana masuk tinggal di cek kodenya untuk melihat pertumbuhan vanding corpored dan vanding retail, Tabungan haji di sini menggunakan retail dari berbagai jamaah, masyarakat, $\mathrm{KBIH}$, akan tetapi nama kemenag menggunkan corpored yang meninduk di kantor pusat.

Implementasi pembiayan Bank Panin Dubai Haji, Tabungan Haji Pas merupakan jenis tabungan yang menggunakan akad Wadiah, dengan jumlah setoran awal tertentu.menggunakan akad Wadiah di mana dana tabungan kalau sudah mencapai 25 juta bisa langsung mendapat bukti setoran BPIH yang sebagai bukti Validasi ke kemenag untuk mendapatkan porsi haji, namun tabungan haji di sini bisa minimal setoran awal 100.000,- dan 
nasabah bisa tiap bulanya bisa menyetor dananya berapa. jika tabungan nasabah sudah mencapai 25 juta akan diinfokan ke nasabah yang di lanjutkan swicing ke kemenag, karena waktu tunggu untuk Ibadah haji sekitar 22 tahun. Jika kemenag sudah ketuk palu untuk keberangkatan haji maka sisa pembanyaran segera di lunasi, di bank panin dubai syariah ini mempunyai produk Rencana Anda, yang setoran awal 5.500.000 akan mendapat hadiah yang di tawarkan yakni elektronik, vaucher belanja, kendaraan bermotor, emas dll. Di sini para nasabah banyak yang memilih emas, karena bisa dijual kembali masuk di rekening. dan setoran tiap bulannya hanya 200.000 selama 10 tahun, dalam waktu 10 total dana yang terkumpul bisa mencapai 30 juta untuk menutupi biaya pelunasan ibadah, hanya 10 tahun persiapan dana sedangkan waktu tunggu pemberangkatan 22 tahun.

Pembukaan Rekening haji di Bank Panin Dubai Syariah tidak beda dengan pembukaan rekening di bank syariah lainnya. Dengan cara calon nasabah mendatangi kantor cabang bank panin terdekat dan menuju ke custemer cervise dengan membawa persyaratan,

1. Kartu Identitas diri yang masih berlaku untuk WNI, dan untuk WNA membawa (paspor dan Kitas/KIMS,

2. Setoran awal minimal Rp 500.000,-

3. Materai 6000 satu buah,

4. Form pembukaan rekening dan slip setoran awal yang telah di sediakan pihak Bank.

Produk Tabungan haji iB

\begin{tabular}{|l|l|}
\hline $\begin{array}{l}\text { Nama } \\
\text { Produk }\end{array}$ & Tabungan Haji iB \\
\hline
\end{tabular}

\begin{tabular}{|c|c|}
\hline Defini & \begin{tabular}{l}
\multicolumn{3}{|c}{ Tabungan Haji iB } \\
adalah simpanan \\
dana pihak ketiga \\
pada bank yang \\
berdasarkan \\
prinsip wadi'ah, \\
dimana dananya \\
tidak dapat \\
dilakukan \\
penarikan, \\
kecuali untuk \\
pemindah bukuan \\
setoran awal \\
biaya \\
penyelenggaraan \\
ibadah haji \\
(BPIH) dalam hal \\
mendapatkan \\
porsi atau \\
pelunasan biaya \\
penyelenggaraan \\
Ibadah Haji \\
(BPIH)
\end{tabular} \\
\hline Akad & Wadi'ah \\
\hline $\begin{array}{ll}\text { Min } & \text { Set } \\
\text { Awal } & \\
\end{array}$ & Rp 500.000,- \\
\hline Saldo Min & Rp 100.000,- \\
\hline $\begin{array}{l}\text { Biaya } \\
\text { Administrasi }\end{array}$ & $\operatorname{Rp} 0,-$ \\
\hline $\begin{array}{l}\text { Biaya } \\
\text { penutupan }\end{array}$ & $\begin{array}{ll}\text { Rp } & 100.000,- \\
\text { "gratis" } & \text { apabila } 6 \\
\text { bulan } & \text { setelah } \\
\text { kepulangan haji } \\
\text { dan atau calon } \\
\text { jamah } & \text { haji } \\
\text { meninggal dunia } \\
\end{array}$ \\
\hline $\begin{array}{l}\text { Saldo porsi } \\
\text { Haji }\end{array}$ & $>25.000 .000$ \\
\hline
\end{tabular}

Bank Panin Dubai Syariah juga juga banyak membuka LSA (Layanan Satu Atap) di berbagai daerah di Jawa Timur yang berkerja sama dengan Kemenag, seperti Jember, Lamongan,Gresik, Dll. Layanan untuk memudahkan para Jamaah 
yang dari berbagai daerah dalam pendaftaran haji. Kebanyakan Jamaah dalam pendaftaran Haji akan larinya ke kemenag namun sekarang pendaftaran harus di lakukan di Bank terlebih dahulu, dengan ini akan di arahkan ke Bank yang telah ada LSA untuk pembuatan rekening tabungan haji, di LSA disini juga langsung mengeluarkan surat bukti Setoran BPIH, bukti Setoran BPIH sebagai syarat bukti ke kemenag, kemenag akan bisa mengeluarkan SPPH (Surat Pendaftaran Pergi Haji) dan mendapatkan Nomor Porsi.

Bank umum yang menjadi mitra pemerintah dalam pengelolaan rekening milik kementrian Negara, dalam rangka implementasi Peraturan Menteri Keuangan Nomor 252 PMK 05.2014, tentang rekening milik Kementrian Negara/ lembaga satuan kerja telahdilakukan penandatangananPerjanjian

kerjasama pelaksanaan Theasury National poling pada Rekening Pemerintah milik kementrian negara satuan kerja antara Kementrian Keuangan RI dan bank umum Bank Panin Dubai Syariah yang telah ditanda tangani perjanjian kerjasama tersebut direkomendasikan kepada seluruh kuasa Pengguna Anggaran dan pemimpin Badan layanan umum dalam rangka pengelolaan keuangan Kementrian Negara Lembaga Satuan Kerja.

Selanjutnya $r$ sesuai
dengan ketentuan umum
perbankan syariah, bahwa untuk
menjamin produk perbankan
syariah sesuai dengan nilai-nilai
syari'at Islam. Pengawasan

penerapan produk perbankan pada Bank Panin dubai syariah cabang Surabaya dilakukan oleh Dewan Pengawas Syariah yang ditetapkan oleh Dewan syariah Nasional MUI. dan pengawasan dari Kementrian Agama Jakarta. Oleh karena itu Bank di tuntut untuk bekerja secara profesional dan memahami aspek-aspek ekonomi Islam.

Berdasarkan uraian tersebut penulis berpendapat bahwa Bank Panin Dubai Syaiah telah menerapkan Peraturan Kementrian Agama No 24 tahun 2016 tetang atas perubahan Peraturan Kementrian Agama No 30 tahun 2013, yaitu "BPS BPIH dilarang memberikan layanan dana talangan haji baik secara langsung maupun tidak langsung". telah sesuai dengan yang di terapkan pada Bank Panin Dubai Syariah yang hanya mengunakan satu akad.

\section{KESIMPULAN}

Berdasarkan paparan dan analisis yang telah diuraikan di atas dapat di simpulkan beberapa hal sebagai berikut:

1. Bank Panin Dubai Syariah menjadi mitra pemerintah dalam pengelolaan rekening milik kementrian Negara, dalam rangka implementasi Peraturan Menteri Keuangan Nomor 252 PMK 05.2014, tentang rekening milik Kementrian Negara/lembaga satuan kerja telah dilakukan penandatangananPerjanjian kerjasama pelaksanaan Theasury National poling pada Rekening Pemerintah milik kementrian negara satuan kerja antara Kementrian Keuangan RI. 
2. Bahwa dalam Produk tabungan dana haji pada Bank Panin dubai Syariah telah sesuai dengan Peraturan Menteri Agama No 24 tahun 2016 tentang perubahan atas Peraturan Menteri Agama No 30 tahun 2013 Bank penerima setoran biaya penyelenggara ibadah haji. Akad Wadiah yang terapkan pada bank untuk tabungan pembiayaan haji dan umrah telah berlaku sesuai dengan ketentuan peraturan pemerintah bahwa BPS BPIH dilarang memberikan layanan dana talangan haji baik secara langsung maupun tidak langsung. Dan akad wadiah juga telah sesuai dengan ketentuan syari'at Islam akad yang di gunakan wadiah yad dhamanah yaitu akad titipan murni dari nasabah kepada bank tanpa diperjanjikan keuntungan, dana tabungan haji yang di titipkan pada bank, jika jumlah tabungan sudah 25 juta, akan di trasfer langsung ke rekening Kemenag.

\section{DAFTAR PUSTAKA}

\section{Referensi Buku}

Abdul. Hadi, Memahami akad-akad dalam perbankan syariah dan dasar-dasar hukumnya, (Surabaya: SinarTerang, 2015)

Abdullah abdul Hasan At Tariqi, Ekonomi ISlam Prinsip Dasar dan Tujuan, (Yogyakarta: Magistra Insane Press, 2004)

Ascarya, Akad dan Produk Bank Syariah, (Jakarta: PT Raja Grafindo Persada, 2007)

Ath-Thayyar Muhammad., Ensiklopedi Fiqih Muamalah; dalam Pandangan 4
Madzhab, (Riyadh: Madar alWathan, 2004).

Anderson Norman, Law reform in the Moslem World (London: The Athlone Press, 1976)

Aziz Dahlan Abdul, Enkslopedi Hukum Islam, (Jakarta: PT Ichtiar Baru Vanvove, 1997)

A Rahman Ritonga dan Zainuddin, Fiqh Ibadah, (Jakarta: Gaya Media Pratama, 2002)

A Djazuli, Lembaga-lemaga Perekonomian umat, sebuah pengantar, (Jakarta, Rajawali Grafindo Persada, 2002)

Antonio Syafi'i, Bank Syariah: dari Teori Praktik, (Jakarta: Gema Insani, 2001)

BurhanuddinSusanto,

HukumPerbankanSyariah di Indonesia, (Yogyakarta, UII Press, 2008), 223

Ditjen Bimas Islam dan Penyelengharaan Ibadah Haji, Realitas \& Tantangan Penyelenggaraan Ibadah Haji, (Jakarta: Ditjen BPIH, 2003)

Fadhul ,Fikih abdullah Ibnu Mas'ud ra. fi Fiqh'il Muamalat, Diraasah

Gufron A. Mas'adi, FiqhMuamalahKonsektual, (Jakarta: Raja Grafindo Persada, 2002)

Gunawan Imam, Metode Penelitian Kualitatif Teori Dan Praktik, (Jakarta: Bumi Aksara, 2016)

GemalaDewi, Wirdyaningsih, HukumPerikatan Islam di Indonesia, (Jakarta: Persada Media, 2005)

Iska Syukri, Sistem Perbankan Syariah di Indonesia dalam Perspektif Fiqih Ekonomi, (Yogyakarta: Fajar Media Press, 2012) 
Kiryanto Ryan, Konversi Bank Konvensional Ke Bank Syariah, (Jakarta: Suara Karya, 2001)

Khalifi Elyas Bahar, Do'a dan amalan agar mendapat Panggilan Ziarah Haji dan Umrah, (Jakarta: Viva Press, 2013)

Kashmir, Manajemen Perbankan (Jakarta: PT Raja Grafindo Perkasa, 2003)

Kamus besar bahasa Indonesia

M. Hasan Ali ,Berbagai macam Transaksi dalam Islam (Fiqh Mu'amalat) (Jakarta: Rajawali Pres, 2003)

Muhammad, Manajemen Pembiayaan Bank Syariah, (Yogyakarta: YKPN, 2005)

Muaqarranah (Saudi Arabia, Ummul Qura, Perss, 2004),

Machmud Amir, Rukmana, Bank Syariah, teori Kebijakan, dan studi Empiris di Indonesia, ( Jakarta, Erlangga, 2010)

Muhammad,

Manajemen

Pembiayaan Bank Syariah (Yogyakarta: UPP, AMM, YKPN, 2002)

Mufti Afif, Analiasis Krisis Implementasi Akad Wadi'ah, Jurnal Ekonomi Islam, 2013

M. Abdus, Shomad, Keraguan Atas Praktik Bank Syariah, Majalah Pengusaha

Mukhtar, Metode Praktis Penelitian Deskriptif Kualitatif, (Jakarta: Referensi, 2013)

Nazir Habib dan Muhammad Hasanuddin, Ensiklopedi Ekonomi dan Perbankan Syariah, (Bandung: Kafa Publising, 2008)

Sjahdeini, Perbankan Islam dan Kedudukannya Dalam Tata Hukum Perbankan Indonesia,
(Jakarta: Pustaka Utama Grafiti, 1999).

Soemitra Andri, Bank dan Lembaga Keuangan Syariah, (Jakarta: Kencana, 2009),

Sumitro Warkum, Asas-asas Perbankan Islam dan Lembaga-lembaga terkait BMUI dan Tafaku, (Jakarta: PT Raja Grafindo, 1996)

Sutedi Andrian, Perbankan syariah: Tinjauan dan Beberapa segi hukum, (Jakarta: Ghalia Indonesia, 2009,)

Soerjono Soekanto dan Sri Mamudji, Penelitian Hukum Normatif, (Jakarta: PT Grafindo persada, 2006)

Sugiono, Metode Penelitian Kuantitatif, Kualitatif dan $R \& D$ (Bandung: Alfabeta, 2014)

Prastowo Andi, Metode Penelitian Kualitatif dalam Perspektif Rancangan Penelitian, ( Jogjakarta: Ar-rum Media, 2014)

Al-Quran Surat Al Imran ayat 97

Waluyo Bambang, Penelitian Hukum dalam Praktik, (Jakarta: Sinar Grafika, 1991)

\section{Undang-undang}

Peraturan Menteri No 24 tahun 2016 tentang perubahan atas peraturan Menteri Agama No 30 tahun 2013 tentang Bank Penerima Setoran biaya Penyelenggaraan Ibadah Haji.

Peraturan Menteri Agama Repubik Indonesia Nomor 30 tahun 2013 tentang Bank Penerima setoran biaya penyelenggaraan ibadah haji

Peraturan Menteri KUKM Nomor 06/Per/K.KUKM/I/2007 Tentang Petunjuk Teknis Program Pembiayaan 
Produktif Koperasi Dan Usaha Mikro (P3KUM)

Pola Syariah, Bab I Ketentuan Umum Bagian Kesatu Pasal 1 ayat 7

Afif Mufti, Jurnal Ekonomi Islam,

FatwaDSN MUI /VIII/2014 tentang Pembiayaan Multijasa

Fatwa DSN MUI No: 01/DSNMUI/IV/2000, tentang Giro

UU No 34 TAHUN 2014 tentang Ibadah Haji,

UU Replubik Indonesia No 13 tahun 2008 tentang penyelenggaraan Ibadah Haji,

UU No 10 tahun 1998 tentang perubahan atas UU no 7 tahun 1992 tentang Perbankan Pasal 1 ayat 12

Muslim, edisi 24, Yogyakarta, Yayasan Bina Pengusaha Muslim Press, (diakses tanggal 15 Januari 2018)

Ijarah Multi Jasa, "http//www.amanahummah.c o.id/, (di akses tanggal 5 Januari 2018)

Warde Ibrahim, Islamic Finance in the Global Economy (Edinburg: Edinburg University, 2000), ( di akses tanggal 22 Januari 2018) 